Review

\title{
NUTRITIONAL FACTORS IN CENTRAL METABOLIC REGULATION
}

\author{
Alfrēds Jānis Sīpols*, ** \\ ${ }^{*}$ Faculty of Medicine, and ** Institute of Experimental and Clinical Medicine, \\ University of Latvia, Ojāra Vācieša iela 4, Rīga, LV-1004, LATVIA \\ sipols@latnet.lv
}

Communicated by Renāte Ligere

\begin{abstract}
The control of metabolism by direct negative feedback of macronutrients detected centrally has been until recently an attractive, though unconfirmed, hypothesis in the homeostatic model of energy regulation. Research advances in the last decade have greatly expanded our knowledge of how circulating carbohydrates, lipids, and proteins, reflecting amounts of recently ingested macronutrients, are detected in hypothalamic areas to not only regulate food intake, but also direct metabolic processes responsible for energy balance and anabolic pathways. For example, plasma glucose sensed centrally is a major regulator of hepatic glucose production, a process most likely mediated by ATP-sensitive potassium channels. More surprising, circulating lipids detected by hypothalamic structures also act as potent negative feedback regulators of glucose mobilization in the liver, independent of their peripheral detection in the intestines. Finally, central detection of circulating postprandial leucine levels has been shown to decrease abdominal fat mass mobilization and thermogenesis. These findings are consistent with the hypothesis that recognition of macronutrients directly by hypothalamic receptors plays a pivotal role in central regulation of metabolic processes. Moreover, the elucidated mechanisms suggest promising potential sites for pharmacological intervention in the treatment of obesity, already at epidemic proportions, although our modern environment is clearly the major cause.
\end{abstract}

Key words: metabolism, regulation, glucose, lipids, proteins, hypothalamus.

\section{INTRODUCTION}

The interaction between human nutrition and metabolic regulation is at once a simple and straightforward relationship characterised by fundamental axioms of metabolic physiology, while at the same time, there are a series of complex associations involving central nervous system mechanisms that orchestrate nearly all facets of this interaction. The guiding principle of this relationship is, of course, homeostasis, and insofar as metabolic processes are intimately concerned with the uptake, storage, and utilisation of energy for a viable organism, central (i.e., brain) processes are an indispensable component in the regulatory scheme. This review, therefore, will highlight some of the recent advances in our understanding of how metabolic processes are regulated centrally, and particularly recognise the roles played by nutritional factors themselves in influencing and, as we shall see, governing many of the mechanisms involved in central metabolic regulation.

The concept of homeostasis by definition involves negative feedback mechanisms to achieve and maintain a steady state involving some parameter, in this case, the body's energy stores. While it may be appealing (and certainly not incorrect) to reduce the relationship between nutrition and metabolism to an energy balance illustration - where one side of the scale contains factors concerning energy uptake and the other containing factors involving energy storage and expenditure - the complexity of the regulatory scheme demands a more rigorous approach to recognise and appreciate the nature of the nutritionally-associated mechanisms active in energy homeostasis. Regarding nutrition, the discipline of endocrinology has focused mainly on hormonal regulation of nutrient intake and energy metabolism, including the interrelationships between anabolic and catabolic processes, the alternative utilisation of fats, carbohydrates or proteins as energy sources, and the nutritional consequences of metabolic diseases. Aside from historical studies highlighting the role iodine plays in thyroid function, calcium in bone metabolism, Vitamin C in scurvy and carbohydrates in diabetes mellitus, it is only relatively recently that researchers have begun to investigate the effects of macro- and micro-nutrients themselves on a wide variety metabolic processes. Therefore, the notion presently addressed is one of ingested nutrients as signals, detected centrally, to alter metabolism. 


\section{GLUCOSE AS A CENTRAL METABOLIC REGULA- TOR}

Central regulation of metabolic processes takes place in the hypothalamus and pituitary gland, and just as mechanisms localised in these central nervous system (CNS) structures are known to influence nutrient selection (among other homeostatic processes in metabolism), so have recent studies revealed the unambiguous extent of nutrient signalling there as well. It is now becoming accepted, along with the traditional view of peripheral detection of macronutrient levels prior to neural transmission of this information to the CNS, that carbohydrates, lipids and proteins are directly sensed in the same hypothalamic structures that receive peripheral neural signals of macronutrient status. For example, maintenance of blood glucose levels, particularly through central regulation of hepatic glucose production (HGP), has been recently studied by a number of investigators, with the roles of insulin and leptin in mediobasal hypothalamic regulation of HPG via a phosphatidylinositol 3-kinase (PI3K) and the Akt signalling pathway now clearly established (Obici et al., 2002; Morton et al., 2005). However, this regulation in the hypothalamic arcuate nucleus (ARC) has also been found to include direct nutrient sensing by agouti-related peptide (AgRP)/neuropeptide Y (NPY)- and proopiomelanocortin (POMC)-expressing neurons of, most prominently, local glucose levels. These specialised glucose-responsive (GR) neurons increase their firing rate as extracellular glucose levels rise, a response based on altered neuronal membrane potential mediated by ATP-sensitive potassium $\left(\mathrm{K}_{\text {ATP }}\right)$ channels (Levin, 2002; Levin et al., 2002). Moreover, chronic hyperglycemia by itself has been shown to decrease the expression of $\mathrm{K}_{\mathrm{ATP}}$ channels in mediobasal hypothalamic neurons (Acosta-Martinez and Levine, 2007), consistent with the notion that elevated glucose levels are eventually met with a decrease in the excitability of ARC neurons, thus preventing excessive stimulation. Together, the aforementioned studies provide compelling evidence that GR neurons of the ARC respond to changes in within the physiologic range of glucose levels in a manner consistent with a central role in glucose homeostasis. Anticipated in vivo studies using microdialysis to more precisely investigate the effects of localised ARC hyper- and hypoglycemia on HGP will be crucial in confirming the general outline of glycemic regulation via central GR neurons (Rother et al., 2008). The exact mechanisms of central glucose sensing, however, still remain elusive, although strong evidence suggests that glucose must first be converted to lactate, followed by hypothalamic stimulation of pyruvate metabolism in order to finally activate the $\mathrm{K}_{\mathrm{ATP}}$ channels (Lam et al., 2005).

\section{LIPIDS AS CENTRAL METABOLIC REGULATORS}

In contrast, the evidence regarding lipid sensing in the CNS, and more specifically, the mechanisms whereby fatty acid metabolism in the hypothalamus can regulate energy homeostasis, is more abundant. As with carbohydrates, the traditional view of lipid metabolism within the small intestine initiating neural signals to regulate whole-body energy homeostasis via CNS-regulated food intake has been supplemented with evidence of two additional factors. The first one is that the detection of lipids in the small intestine also activates a neuronal gut-brain-liver axis to independently regulate HGP, hence peripheral glucose homeostasis. This axis, parenthetically, is currently being exploited in gastric-bypass surgery to restore normal plasma glucose levels in markedly obese individuals with type 2 diabetes mellitus (T2DM) prior to any substantial weight loss (Cummings, 2009). The second one is that lipid-derived metabolites directly activate protein kinase $\mathrm{C}$ (PKC) isoforms in the hypothalamus, impairing not only central action of insulin and leptin (Benoit et al., 2009), but also independently lowering HGP (Ross et al., 2008). Therefore, one major implication from these findings is that lipid sensing, both peripheral and central, independently and together, is a crucial component in maintaining glucose homeostasis, and as already pointed out, offers an attractive opportunity for present and future therapeutic approaches in treating carbohydrate-based metabolic disorders. Paradoxically, the nature and extent of lipid sensing to specifically regulate lipid homeostasis itself remains to be understood, although it has been demonstrated that increased fatty acid levels result in an elevation in the hypothalamic pool of long chain fatty acids-coenzyme As (LCFA-CoAs), which in turn leads to the inhibition of fatty acid oxidation (Lam et al., 2005). Nevertheless, peripheral lipid homeostasis is tightly regulated in the CNS by a variety of neurotransmitter systems in the hypothalamus (Lam, 2010), and further investigation is required to reveal which, if any, of these systems are directly impacted by extracellular lipid levels.

\section{PROTEINS AS CENTRAL METABOLIC REGULATORS}

Although proteins are not thought of as traditional energy sources for the body, they are an indispensable component of macronutrient metabolism insofar as dietary composition is considered. Therefore, their value is not as a fuel source per se, but as a determinant of caloric density of ingested foods, and one important facet of the central regulation of food intake involves differential hypothalamic responses to diets as a function of their composition. The majority of research on protein sensing in the organism has investigated gut mechanisms for two specific reasons: 1) proteins usually are subject to slower and more intensive oral, gastric and intestinal biotransformation into metabolites ready for absorption into the circulatory system than are carbohydrates and lipids, which consist of standard molecular structures (saccharides and triglycerides) relatively easily transported into the portal circulation, and 2) the basic energy currency of the body remains glucose and (to a lesser extent) free fatty acids, and internal signalling concerning their availability is presumably more crucial for short-term viability than relaying information about protein levels. It is therefore understandable that apical intestinal receptors for amino acids and protein (e.g., T1R1/T1R3 heterodimer, cacium-sensing receptor and GPR93) in the lumen of the 
gut have been well characterised (Rasoamanana et al., 2012), as opposed to similar counterparts located in the $\mathrm{CNS}$, at least until recently. These receptors then initiate transmission of information via vagal afferents to hypothalamic structures regulating initiation, maintenance and cessation of food intake. Bearing in mind the time course of meals and the dynamics of food intake, including the kinds of macronutrients present and their relative proportions, the messages from these apical receptors have been considered to be the initial signal in a series of neural responses that initiate central mechanisms of satiety to limit the size of meals. This peripheral sensing of macronutrients, including proteins, has now become a fairly well-characterised and generally accepted model of how basic information concerning ingested nutrients is generated before transmission to the CNS. Therefore, peripheral detection of proteins (and peptides and amino acids), and the resultant central regulation of food intake, has been a prominent scheme regarding proteins as nutrients (versus hormones or enzymes, for example) in central metabolic processes.

Aside from dietary deficits of the essential amino acids or proteins in general leading to compromised anabolic protein processing characteristic of protein-energy malnutrition diseases (e.g., kwashiorkor), meal composition effects with regards to central regulation have only recently been studied. One focus has been to examine the possible involvement of the hypothalamic type 4 melanocortin receptor (MCR4) system in mediating the hunger-curbing effects of protein-enriched diets. Interestingly, notwithstanding the evidence that the MCR4 system is one of the primary anorectic signals through which most satiety actions are thought to occur, the inhibition of eating induced by a protein-enriched diet does not appear to involve MCR4 signalling (Pillot et al., 2011).

Nevertheless, central recognition of specific circulating proteins and amino acids, having previously been speculative, is now also becoming recognised. Evidence is mounting that direct CNS sensing of the essential amino acid leucine is a key step in regulating energy expenditure, as leucine deprivation results in decreased abdominal fat mass through increased lipolysis in white adipose tissue and increased thermogenesis in brown adipose tissue (Cheng et al., 2010). This effect appears to be mediated by increased expression of mediobasal hypothalamic corticotropin-releasing hormone, as well as activation of the sympathetic nervous system. Moreover, intracerebroventricular replacement of leucine, notwithstanding leucine deprivation, attenuates this effect as well as reverses the above-mentioned putative mediatory mechanisms (Cheng et al., 2011), thereby providing solid evidence of CNS regulation of fat metabolism through central recognition of leucine. In addition, leucine signaling in the mediobasal hypothalamus is also mediated downstream by oxytocin neurons in the hypothalamic paraventricular nucleus, as well as neurons in the brainstem nucleus of the solitary tract, to acutely suppress food intake by reducing meal size (Blouet et al., 2009). These findings, along with observations that postprandial plasma and cerebrospinal fluid leucine levels reflect dietary leucine, that leucine enters the CNS more quickly than other amino acids, and that it represents a signal of amino acid abundance for numerous anabolic pathways, including protein synthesis (Nair et al., 1992), taken together provide compelling evidence that leucine is a heretofore unrecognised major determinant of central metabolic regulation. With regards to food intake, it remains to be seen whether leucine signalling is specific for regulation of protein content in meals or functions as a complementary system supporting carbohydrate and/or lipid metabolism, but its central role along with glucose and free fatty acids is now well established.

\section{IMPLICATIONS FOR CLINICAL APPLICATIONS}

The clinical relevance of these findings cannot be underscored enough. With observations that 1) hypothalamic nutrient sensing is impaired in many animal models of obesity, 2) disruption in hypothalamic nutrient sensing results in disregulation of energy homeostasis and obesity, and 3) restoration of hypothalamic nutrient sensing restores energy equilibrium and body weight (Blouet and Scwartz, 2010), it is clear that recognition of macronutrients directly by hypothalamic receptors plays a pivotal role in central regulation of metabolic processes. These receptors, along with the sites of downhill neural and chemical information transfer until eventual action at CNS feeding centres, offer heretofore untested opportunities for pharmacological intervention at specific biochemical and structural targets in the treatment of obesity. These opportunities, however, are not without very fundamental challenges owing to their location; with potential targets sequestered in a privileged site beyond the blood-brain barrier, any successful humorally-based intervention will have to surmount this substantial boundary in order to exert direct action at the hypothalamus. Genetic interventions based on viral vectors allowing DNA incorporation may also be promising, but any such therapeutic strategy, be it genetic or pharmaceutical, will demand concerted efforts in the laboratory to refine the parameters of action (i.e., specificity) while limiting nontherapeutic or secondary effects.

Meanwhile, the ever-increasing epidemic of obesity worldwide, as globalisation expands, keeps a steady drumbeat that is heard by public health authorities throughout the developed and developing world, but who are seemingly powerless to slow it down, let alone reverse it. In this regard, there are many paradigms offered to explain this state of affairs, most notably (and not inaccurately) the trend for more sedentary life styles accompanied by increasing opportunities for overnutrition. These complementary changes in the last half-decade portend ruinous effects on national health budgets already straining with expenditures in an effort to treat overweight- and obesity-related diseases, ranging from cardiovascular to endocrine to oncological to orthopedic disorders. A deeper analysis, however, is prompted by the question of why such a disorder in energy homeostasis, referring to excess weight, has become so prevalent in the last few decades. Regarding changes in physiology, one need 
look no further than the effect of environment on each new generation, particularly prenatally and postnatally. There is now ample evidence that excess maternal body weight during gestation is associated with a host of disorders in children as they reach adulthood, most notably an increased risk of cardiometabolic diseases such as obesity, impaired glucose-insulin homeostasis and pancreatic function, dyslipidemia, non-alcoholic fatty liver disease, hypertension, and other components of metabolic syndrome (Drake and Reynolds, 2010). One likely mechanism of these diseases is the change observed in many aspects of central appetite circuitry, including a decrease in GLUT4, the type 4 insulin-regulated glucose transporter, which is a necessary factor involved in brain glucose sensing (Chen et al., 2008). Hence, children of obese mothers may well be "blind" to central glucose levels notwithstanding (and contributing to) their already present hyperglycaemia.

It must be noted, however, that not all (or even most) obese adults are the offspring of obese mothers during gestation. Nevertheless, this does not preclude the effect of postnatal environmental influences that also may impact hypothalamic nutrient sensing. The most prominent effect that certainly seems to point back directly to the CNS is that provided by the cortico-limbic pathways concerned with learning, memory, mood, emotion and reward. Loosely denoted as the "brain reward system", this collection of neurons, neurotransmitters and nuclei has been widely studied in the context of development and persistence of behaviours that are interpreted as pleasurable or rewarding, most notably those characterising substance abuse. Appetitive behaviours, however, have also been studied in the context of cortico-limbic activation (Figlewicz, 2003), and there is mounting evidence that the brain reward system is increasingly stimulated in our modern environment through availability, portion size, energy density, palatability, variety, and presence of food cues to modulate feedback from nutrient repletion signals. Moreover, the defence of the upper limits of body weight in humans have weakened considerably over that last millenia with loss of selection pressure, something not observed in non-domesticated animals (Zheng et al., 2009). Coupled with the notion that there is a natural tendency to discount (or adjust to) chronically altered negative feedback signals (e.g., insulin or leptin resistance in the obese), it should not be surprising that the effect of our modern environment, as mediated by the brain reward system, is to interfere with the various macronutrient signalling systems.

\section{CONCLUSION}

Recent studies have revealed the remarkable symmetry in mediobasal hypothalamic sensing of circulating carbohydrates, lipids and proteins to regulate metabolic processes concerned with energy stores and biological viability. These pathways offer attractive sites for possible clinical strategies in the treatment of obesity. However, the effects of our modern evironment may be overriding the CNS macro- nutrient feedback signals by activation of cortico-limbic pathways signaling reward and pleasure, and therefore it is imperative that any successful, widely implemented therapeutic approach to treating obesity contain strategies (social as well as psychological) that address the competing activation of the brain reward system.

\section{Declaration of interest}

The author declares that there is no conflict of interest that could be perceived as prejudicing the impartiality of this review.

\section{REFERENCES}

Acosta-Martinez, M., Levine, J.E. (2007). Regulation of $\mathrm{K}_{\mathrm{ATP}}$ channel subunit gene expression by hyperglycemia in the mediobasal hypothalamus of female rats. Amer. J. Physiol. Endocrinol. Metab., 292, E1801-E1807.

Benoit, S.C., Kemp, C.J., Elias, C.F., Abplanalp, W., Herman, J.P., Migrenne, S., Lefevre, A., Cruciani-Guglielmacci, C., Magnan, C., Yu, F., Niswensder, K., Irani, B.G., Holland, W.L., Clegg, D.J. (2009). Palmitic acid mediates hypothalamic insulin resistance by altering PKC-theta subcellular localization in rodents. J. Clin. Invest., 119, 2277-2589.

Blouet, C., Jo, Y., Li, X., Schwartz, G.J. (2009). Mediobasal hypothalamic leucine sensing regulates food intake through activation of a hypothalamus-brainstem circuit. J. Neurosci., 29, 8302-8311.

Blouet, C., Schwartz, G.J. (2010). Hypothalamic nutrient sensing in the control of energy homeostasis. Behav. Brain Res., 209, 1-12.

Chen, H., Simar, D., Lambert, K., Mercier, J., Morris, M.J. (2008). Maternal and postnatal overnutrition differentially impact appetite regulators and fuel metabolism. Endocrinology, 149, 5348-5356.

Cheng, Y., Meng, Q., Xia, T., Wang, C., Li, H., Huang, Z., Chen, S., Xiao, F., Du, Y., Guo, F. (2010). Leucine deprivation decreases fat mass by stimulation of lipolysis in white adipose tissue and upregulation of uncoupling protein 1 (UCP1) in brown adipose tissue. Diabetes, 59, 17-25.

Cheng, Y., Zhang, Q., Meng, Q., Xia, T., Huang, Z., Wang, C., Liu, B., Chen, S., Xiao, F., Du, Y., Guo, F. (2011). Leucine deprivation stimulates fat loss via increasing $\mathrm{CRH}$ expression in the hypothalamus and activating the sympathetic nervous system. Mol. Endocrinol., 25, 1624-1635.

Cummmings, D.E. (2009). Endocrine mechanisms mediating remission of diabetes after gastric bypass surgery. Int. J. Obes. (London), 33 Supp 1, S33-S40.

Drake, A.J., Reynolds, R.M. (2010). Impact of maternal obesity on offspring obesity and cardiometabolic disease risk. Reproduction, 140, 387-398.

Figlewicz, D.P. (2003). Adiposity signals and food reward: Expanding the CNS roles of insulin and leptin. Amer. J. Physiol. Regul. Integr. Comp. Physiol., 284, R882-R892.

Lam, T.K. Neuronal regulation of homeostasis by nutrient sensing. Nat. Med., 16, 392-395, 2010.

Lam, T.K., Gutierrez-Juarez, R., Pocai, A., Rossetti, L. (2005). Regulation of blood glucose by hypothalamic pyruvate metabolism. Science, 309, 943-947.

Lam, T.K., Schwartz, G.J., Rosetti, L. (2005). Hypothalamic sensing of fatty acids. Nat. Neurosci., 8, 579-584.

Levin, B.E. (2002). Glucosensing neurons: The metabolic sensors of the brain? Diabetes Nutr. Metab., 15, 274-281.

Levin, B.E., Dunn-Meynell, A.A., Routh, V.H. (2002). CNS sensing and regulation of peripheral glucose levels. Int. Rev. Neurobiol., 51, 219-258.

Morton, G.J., Gelling, R.W., Niswender, K.D., Morrison, C.D., Rhodes, C.J., Schwartz, M.W. (2005). Leptin regulates insulin sensitivity via phosphatidylinositol-3-OH kinase signaling in mediobasal hypothalamic neurons. Cell Metab., 2, 411-420. 
Nair, K.S., Schwartz, R.G., Welle, S. (1992). Leucine as a regulator of whole body and skeletal muscle protein metabolism in humans. Amer. J. Physiol., 263, E928-E934.

Obici, S., Zhang, B.B., Karkanias, G., Rossetti, L. (2002). Hypothalamic insulin signaling is required for inhibition of glucose production. Nat. Med., 8, 1376-1382.

Pillot, B., Duraffourd, C., Begeot, M., Joly, A., Luquet, S., Houberdon, I., Naville, D., Vigier, M., Gautier-Stein, A., Magnan, C., Mithieux, G. (2011). Role of hypothalamic melanocortin system in adaptation of food intake to food protein increase in mice. PLOS ONE 6, e19107.

Received 12 July 2012
Rasoamanana, R., Darcel, N., Fromentin, G., Tomé, D. (2012). Nutrient sensing and signalling by the gut. Proc. Nutr. Soc., 27, 1-10.

Ross, R., Wang, P.Y., Chari, M., Lam, C.K., Caspi, L., Ono, H., Muse, E.D., Li, X., Gutierrez-Juarez, R., Light, P.E., Schwartz, G.J., Rossetti, L., Lam, T.K. (2008). Hypothalamic protein kinase $\mathrm{C}$ regulates glucose production. Diabetes, 57, 2061-2065.

Rother, E., Konner, A.C., Bruning, J.C. (2008). Neurocircuits integrating hormone and nutrient signaling in control of glucose metabolism. Amer. J. Physiol. Endocrinol. Metab., 294, E810-E816.

Zheng, H., Lenard, N., Shin, A., Berthoud, H.R. (2009). Appetite control and energy balance regulation in the modern world: Reward-driven brain overrides repletion signals. Int. J. Obes. (London), 33, S8-S13.

\section{UZTURVIELU FAKTORI VIELMAIN̦AS CENTRĀLAJĀ REGULĀCIJĀ}

Vielmaiņas kontrolēšana ar centrāli uztverto makrovielu tiešo negatīvo atgriezenisko saiti vēl nesen ir bijusi saistoša, tomēr neapstiprināta hipotēze enerğijas regulācijas homeostāzes modelī. Panākumi pētniecībā pēdējā desmitgadē ir būtiski paplašinājuši mūsu zināšanas par to, kā og̣̣hidrāti, taukvielas, un olbaltumvielas asinsritē, kuri atspoguḷo tikko uzņemto makrovielu daudzumu uzturā, tiek uztverti hipotalāma reǵionos, ne tikai regulējot uztura uzṇemšanu, bet arī vadot vielmainas procesus, kas ir atbildīgi par enerğijas līdzsvaru un anaboliskiem posmiem. Piemēram, centrāli uztvertā glikoze plazmā ir nozīmīgs glikozes ražošanas regulators aknās — tas ir process, ko visdrīzāk mediē ATF-jutīgi kālija kanāli. Vēl pārsteidzošāk, taukvielas asinsritē, kas ir uztvertas hipotalāma reğionos, arī funkcionē kā spēcīgi negatīvās atgriezeniskās saites regulatori glikozes mobilizācijai aknās, neatkarīgi no taukvielu perifērās uztveršanas zarnās. Visbeidzot, centrāli uztvertie leicīna līmeṇi asinsritē pēc ēšanas samazina vēdera tauku masas mobilizāciju un termoǵenēzi. Šie atklājumi saskan ar hipotēzi, ka makrovielu uztveršanai tieši hipotalāma receptoros ir izšḳiroša loma vielmainas procesu centrālajā regulācijā. Turklāt šie noskaidrotie mehānismi norāda uz potenciāli daudzsološām iespējām farmakoloğiskai intervencei, ārstējot aptaukošanos, kas jau sasniegusi epidēmijas līmeni, kaut gan mūsu modernās vides ietekme neapšaubāmi ir aptaukošanās galvenais cēlonis. 